\title{
Bacterial involvement in determining domoic acid levels in Pseudo-nitzschia multiseries cultures
}

\author{
James E. Stewart* \\ Ecosystem Research Division, Department of Fisheries and Oceans, Bedford Institute of Oceanography, PO Box 1006 , \\ Dartmouth, Nova Scotia B2Y 4A2, Canada
}

\begin{abstract}
This study examining factors contributing to the production or elimination of domoic acid (DA) in cultures of Pseudo-nitzschia multiseries showed that in axenic cultures doubling the silicate concentrations increased growth, but not DA levels. DA concentration for axenic cultures was increased by the addition of gluconolactone (GlcA), especially in cultures with increased silicon. In non-axenic cultures, there were similar increases in growth with increased silicon, but a reduction of DA production in the presence of GlcA. Detailed examinations confirmed these findings and also showed that in non-axenic cultures, glucose alone resulted in a reduction of DA while a combination of glucose with gluconolactone resulted in a complete elimination of DA. Subsequent trials with axenic $P$. multiseries cultures showed that additions of DA or DA plus glucose introduced at the early stationary growth phase and incubated for $5 \mathrm{~d}$ had no impact on DA concentrations. In contrast, a $6 \mathrm{~d}$ incubation of the associated bacteria separated from the non-axenic diatom cultures showed reductions of added DA concentrations ranging from 46 to $72 \%$, depending upon co-additives. The diatom does not use extracellular DA present in surrounding culture medium whereas bacteria associated with the diatom can utilize DA readily. Reductions in the production of DA by aging $P$. multiseries cultures appear to be the result of changing balances over time among bacteria associated with the diatom. These data coupled with results from other studies indicate that the amount of DA measured in $P$. multiseries cultures is a result of competitive interaction, i.e. a function of the diatom's production rate versus the extra-cellular utilization of DA by associated bacteria.
\end{abstract}

KEY WORDS: Domoic acid • Diatom • Pseudo-nitzschia multiseries · Silicon • Gluconolactone • Glucose

\section{INTRODUCTION}

In 1987, the neurotoxic properties of domoic acid (DA) were revealed by a major episode of acute human poisoning (Bird et al. 1988, Subba Rao et al. 1988, Bates et al. 1989, Wright et al. 1989, Perl et al. 1990, Todd $1990,1993)$. This poisoning resulted from consumption of farmed blue mussels Mytilus edulis from Cardigan, Prince Edward Island, Canada that possessed concentrations of DA ranging up to $900 \mathrm{\mu g} \mathrm{g}^{-1}$ of soft tissue (Quilliam et al. 1989, Wright et al. 1989). The source of the DA was the diatom (Subba Rao et al. 1988, Bates et al. 1989) Pseudo-nitzschia multiseries (Hasle 1995) upon which the mussels had been feeding. At least
3 people died as a result of the intoxication and 150 others were considered to have been poisoned. As one of the effects of the severe poisonings was loss of short-term memory, the DA intoxication was named Amnesic Shellfish Poisoning (ASP) (Perl et al. 1990).

Subsequently, DA has been found widely in the marine environment (Villac et al. 1993, Rhodes et al. 1998, Bates 2000) largely, but not exclusively, produced by Pseudo-nitzschia species. The production of DA has been reported also for one strain of a pennate diatom, Amphora coffeaeformis (Shimizu et al. 1989) and from Nitzschia navis-varingica isolated from a shrimp culture pond in Vietnam (Kotaki et al. 2000, Lundholm \& Moestrup 2000). 
Pseudo-nitzschia multiseries usually proliferates at a time of year when conditions are unfavourable for other algal species, i.e. light is low and most species of algae are unable to grow optimally (Mos 2001, Hagström et al. 2007). Blooms occur usually in spring and late fall when phosphorous and silicate are depleted in surface waters and nitrogen is relatively high as a result of rain and melting snow increasing its transport from land to sea (Bates 1998).

DA is produced in volume by Pseudo-nitzschia multiseries only after it has reached the stationary phase of growth, i.e. upon depletion of nutrients (Subba Rao et al. 1990, Bates et al. 1991). Importantly, the DA produced is not retained by diatom cells, but instead most is excreted to the surrounding medium (Subba Rao et al. 1990, Bates et al. 1991). Imposing nutrient stress on cells growing non-axenically by limiting nitrate and silicate (Bates et al. 1991), silicate (Pan et al. 1996a,b) phosphate (Pan et al. 1996c), or by supplying nitrogen in the form of ammonium ions in excess of $110 \mu \mathrm{M}$ (Bates et al. 1993) slows the rate of cell division and concomitantly increases DA production. Conversely, DA production is increased without affecting the growth rate of non-axenically grown cells by adding $\mathrm{LiCl}$ to the medium at a concentration of $385.6 \mu \mathrm{M}$; this induces a DA increase in the stationary phase considerably earlier than DA increased in control cultures (Subba Rao et al. 1998). In addition, Douglas \& Bates (1992) and Bates et al. (1995) showed that the low production of DA by axenic cultures of $P$. multiseries was enhanced by introduction of particular bacteria to these cultures.

Following the identification of gluconolactone in the fluid of only those mussels containing DA (McLachlan et al. 1993), Stewart et al. (1997) demonstrated that certain bacteria associated with each Pseudo-nitzschia multiseries strain examined were strong producers of gluconolactone. Exposure of $P$. multiseries during axenic growth to gluconolactone, or more precisely to the resultant powerful, sequestering gluconic acid/ gluconolactone (GlcA) mixtures, produces no interference with growth, but enhances DA production in the stationary phase in proportion to the concentrations of GlcA added (Osada \& Stewart 1997). Osada \& Stewart (1997), on the basis of the antagonistic, sequestering nature of the GlcA mixtures and the observations by others of the effects of nutrient stress, suggested that the DA could be generated by the diatom as an external chemical scavenger to counter nutrient stress.

DA is utilized by bacteria isolated from shellfish (blue mussels and soft shell clams, Mya arenaria) and by bacterial strains isolated from Pseudo-nitzschia multiseries cultures [strains N-7, a Moraxella species and N-9, an Alteromonas species (Stewart et al. 1997)] (Stewart et al. 1998). All of these bacteria supplied with low concentrations of growth factors readily cause the disappearance of DA presented in moderate concentrations of 40 or $80 \mathrm{nM}$. Thus this information (and the studies by Hagström et al. (2007) showing the ultimate destruction of DA by bacteria associated with the diatom in aged and decaying cultures) suggest that the bacteria associated with the diatom can be factors in determining the production levels of DA and its elimination under particular circumstances.

Bacterial associations and their involvement with DA-producing diatoms were examined by Douglas \& Bates (1992), Bates et al. (1995), Stewart et al. (1997, 1998), Osada \& Stewart (1997), Kaczmarska et al. (2005) and Hagström et al. (2007). In this study, questions on the dynamics of DA formation by Pseudonitzschia multiseries and the various factors (including bacteria) which may influence its production and elimination are considered. These include: (1) As a wide variety of nutrient stresses contribute to DA production, i.e. reduced silicate, phosphorous, nitrate etc., what effect would increases in various factors, e.g. silicate, an energy source (glucose) or a sequestering agent (gluconic acid/gluconolactone) have on diatom growth and DA production in axenic and non-axenic cultures? (2) Are declines in DA production in culture a result of its re-absorption by the diatom or degradation by associated bacteria?

\section{MATERIALS AND METHODS}

The DA-producing strain (designated $\mathrm{NpH}$ ) of Pseudo-nitzschia multiseries used throughout this work and in previous studies (Osada \& Stewart 1997, Stewart et al. 1997) was isolated originally by K. E. Pauley (strain KP59) from New London Bay, Prince Edward Island, Canada on October 18, 1991.

All diatom growth studies were carried out in triplicate (except in one instance as noted) in the appropriate medium usually dispensed in $20 \mathrm{ml}$ quantities in $50 \mathrm{ml}$ capacity polystyrene sterile tissue culture flasks (Nunc). Cultures were maintained at $20^{\circ} \mathrm{C}$ in a continuous cool-white fluorescent light regime at 170 (range 140-200) $\mu \mathrm{mol}$ photons $\mathrm{m}^{-2} \mathrm{~s}^{-1}$ (QSL light meter, Biospherical Instruments). The growth medium was a modification of that proposed by Harrison et al. (1980); steam-sterilized trace metals and nutrients (minus silicate and boric acid, and with $\mathrm{NaH}_{2} \mathrm{PO}_{4}$ substituted for glycerophosphate) were added aseptically to steam-sterilized natural sea water (taken from bulk supplies collected from Bedford Basin, Nova Scotia, Canada in the fall of 1990, passed through a $53 \mu \mathrm{m}$ pore size filter and stored unsterilized in closed containers at room temperature) followed by the aseptic addition of a vitamin mixture and $1 \mathrm{ml} \mathrm{l}^{-1}$ of a $(0.1 \mathrm{M})$ 
$\mathrm{Na}_{2} \mathrm{SiO}_{3} \cdot 9 \mathrm{H}_{2} \mathrm{O}$ sterile solution to give a final silicate concentration of $0.1 \mathrm{mM}$ in the basal medium, the salinity of which was approximately $33 \mathrm{psu}$.

Axenic Pseudo-nitzschia multiseries subcultures were prepared as described earlier (Osada \& Stewart 1997) by treating non-axenic liquid cultures with ampicillin (1 $\mathrm{mg} \mathrm{ml}^{-1}$ of culture medium) overnight, or with mixtures of ampicillin $\left(1 \mathrm{mg} \mathrm{ml}^{-1}\right)$ and streptomycin $\left(2 \mathrm{mg} \mathrm{ml}^{-1}\right)$ for $72 \mathrm{~h}$, followed by subculture in fresh antibiotic-free medium. Subcultures were examined microscopically and bacteriologically using DIFCO Marine Agar and Broth (\#2216). The subcultures in which no bacteria were observed or could be cultured were used for axenic studies; identical examinations were carried out after the completion of studies to ensure that the cultures were still axenic.

From each culture flask, $2 \mathrm{ml}$ samples were removed on the sampling days indicated for determination of diatom numbers and chemical concentrations. Diatom numbers were determined by direct microscopic counts using $0.5 \mathrm{ml}$ of the material removed from the growth flasks, mixed with fixative $(2 \%$ final concentration of 1:1 formalin:glacial acetic acid) and settled in glass-bottomed counting chambers.

Additives for use in growth experiments were dissolved in distilled water to give concentrated solutions which when introduced would result in minimal dilution of the media $(<0.5 \%)$, i.e. GlcA adjusted to $\mathrm{pH} 8.0$ with $\mathrm{NaOH}$ and made up to $100 \mathrm{mM}$ and glucose prepared as a 1.0 M solution. These were filter sterilized (0.22 $\mu \mathrm{m}$ pore size filter) and added as required to sterile growth media to give the desired final concentrations. Silicate concentrations were increased by addition of the appropriate amounts of the sterile silicate medium supplement always added to the medium prior to inoculation with Pseudo-nitzschia multiseries.

For tracking DA concentrations in the diatom growth studies, samples were withdrawn aseptically, and stored frozen for later treatment. The cells were ruptured by treatment for $1 \mathrm{~min}$ with a Sonic Dismembrator (Artek System) equipped with a titanium microtip and operated at $35 \%$ power (about $100 \mathrm{~W}$ ). The resulting homogenate was centrifuged $(10000 \times g$ for $10 \mathrm{~min}$ ) to remove debris; the supernatant fluids containing the extra- and/or intra-cellular DA were stored frozen to await analysis.

Using sterile techniques to avoid contamination, mixtures of bacteria associated with Pseudo-nitzschia multiseries cultures were separated from the diatom by filtration through a $3 \mu \mathrm{m}$ pore size membrane filter. Upon microscopic examination of the filtrate, no intact diatom cells were detected; aliquots of this filtrate transferred to the standard diatom medium did not exhibit growth of diatom cells even after $10 \mathrm{~d}$ incubation at $20^{\circ} \mathrm{C}$.
The bacterial mixtures obtained were used to inoculate the yeast extract broth basal medium of MacLeod (1968) dispensed in quadruplicate in $225 \mu$ quantities into sterile 96-well microplates. Each well was inoculated with $25 \mu \mathrm{l}$ of the freshly prepared bacterial mixtures and incubated in the dark at $20^{\circ} \mathrm{C}$ in parallel with control wells containing $250 \mu \mathrm{l}$ of the uninoculated medium. Growth was recorded as optical density at $590 \mathrm{~nm}$ using a microplate reader (Molecular Devices). On the 6th day of incubation, the contents of the wells were subjected to centrifugation $(10000 \times g)$ to remove bacteria, and the DA concentrations in the supernatant fluids were determined.

DA was determined using the enzyme-linked immunosorbent assay (ELISA) specific for DA (Osada et al. 1995) except for the trials in which the DA was added to axenic cultures of Pseudo-nitzschia multiseries (determined by the High Pressure Liquid Chromatography (HPLC) as described by Gilgan et al. 1990). For ELISA analyses, $180 \mu \mathrm{l}$ of 10-fold PBS dilutions of the supernatant fluids from sonic treated whole cultures were dispensed into each well of the 96-well microplates previously coated with DA conjugated with ovalbumin and blocked with bovine serum albumin. The contents were then treated as described by Osada \& Stewart (1997).

Glucose and GlcA concentrations were measured in culture filtrates according to the manufacturers' directions using the appropriate specific enzymatic combinations supplied by Boehringer Mannheim Canada; glucose supplied to the axenic cultures was determined using the Megazyme International Ireland Assay Kit.

\section{RESULTS}

The growth of axenic Pseudo-nitzschia multiseries (strain $\mathrm{NpH}$ ) cultures alone or in the presence of additives is shown in Fig. 1 along with data on the influence of these additives on DA production. As expected, the doubling of the silicate concentration increased cell production although at neither level of silicate did the axenic culture prove to be robust or stable. As observed initially by Osada \& Stewart (1997), the $0.25 \mathrm{mM}$ GlcA concentrations had no apparent effect upon growth. There were differences, however, in the DA production. When $0.25 \mathrm{mM}$ GlcA and $0.2 \mathrm{mM}$ silicate were combined, the DA production was tripled (Fig. 1). Significant DA production with these cultures actually began considerably after cell division had peaked and did not reach maximum values until the cultures were in severe decline.

As preliminary trials with axenic Pseudo-nitzschia multiseries cultures indicated that concentrations of 


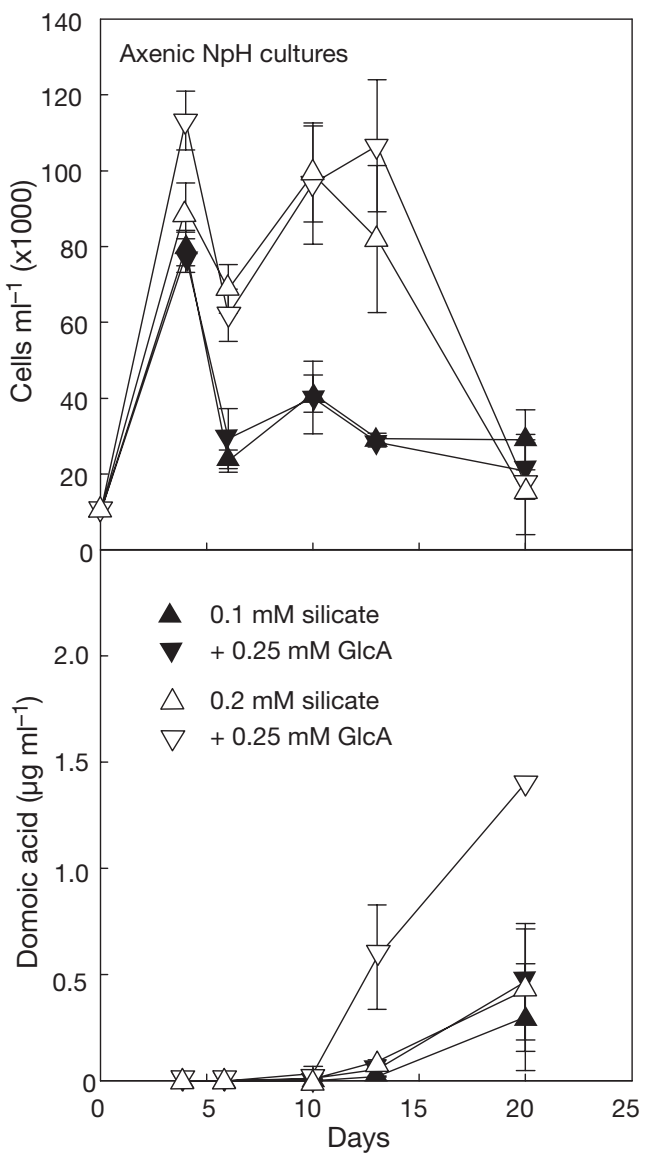

Fig. 1. Pseudo-nitzschia multiseries. Growth of axenic cultures (strain $\mathrm{NpH}$ ) and production of DA (domoic acid) at $20^{\circ} \mathrm{C}$ in standard diatom medium alone (0.1 $\mathrm{mM}$ silicate) and when supplemented to concentrations of $0.25 \mathrm{mM}$ gluconolactone (GlcA)/gluconic acid, or also doubling the silicate concentration ( $0.2 \mathrm{mM}$ silicate). All supplements were present from the initiation of the growth period. Means \pm SE $(n=3)$

added GlcA remained unchanged, a virtual repetition of part of the previous experiment was run for confirmation. Axenic P. multiseries was grown in the standard diatom medium increased to $0.2 \mathrm{mM}$ silicate and half of the flasks (4) were brought to $0.5 \mathrm{mM}$ GlcA on the 8th day post inoculation (the remainder (4) had no additives). The measurements made on the 18th day of

Table 1. Pseudo-nitzschia multiseries. Effects of GlcA (gluconolactone) addition on DA (domoic acid) production in axenic culture. Means $\pm \mathrm{SE}, \mathrm{n}=4$

\begin{tabular}{|c|c|c|c|c|}
\hline \multirow{2}{*}{$\begin{array}{l}\text { Cell density } \\
\left(\text { cells ml }{ }^{-1} \text { ) }\right.\end{array}$} & \multirow{2}{*}{$\begin{array}{c}\text { GlcA added } \\
\text { on Day } 8\end{array}$} & \multirow{2}{*}{$\begin{array}{c}\mathrm{DA}\left(\mathrm{ng} \mathrm{ml} l^{-1}\right) \\
\text { at Day } 18\end{array}$} & \multicolumn{2}{|c|}{$\longrightarrow$ GlcA $\left(\mu \mathrm{g} \mathrm{ml}^{-1}\right)$} \\
\hline & & & Initial (Day 8) & Final (Day 18) \\
\hline $71610 \pm 11685$ & 0.0 & $830 \pm 387$ & 0.0 & 0.0 \\
\hline $81840 \pm 5391$ & $\begin{array}{c}\left.0.5 \mathrm{mM}^{-1}\right) \\
\left(133 \mathrm{~g} \mathrm{~m} \mathrm{ml}^{-1}\right.\end{array}$ & $1600 \pm 533$ & $\begin{array}{l}133 \pm 2.1 \\
134 \pm 8.4\end{array}$ & $\begin{array}{l}124.3 \pm 3 \\
121.3 \pm 19.4\end{array}$ \\
\hline
\end{tabular}

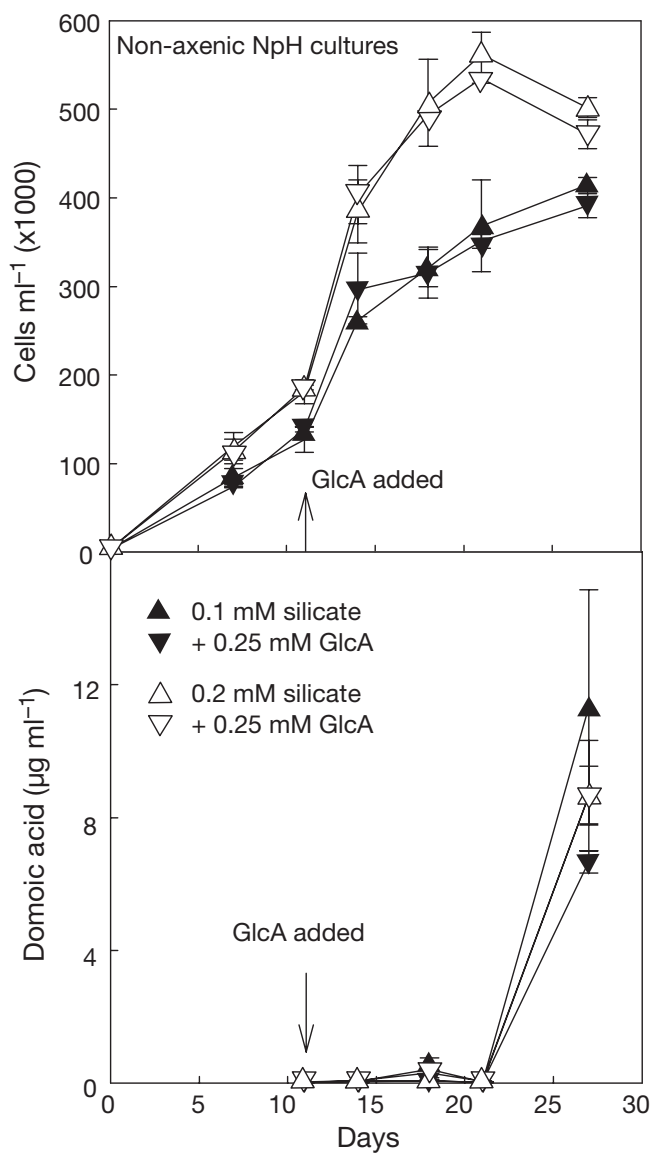

Fig. 2. Pseudo-nitzschia multiseries. Growth of non-axenic cultures (strain $\mathrm{NpH}$ ) and production of DA (domoic acid) at $20^{\circ} \mathrm{C}$ under the influence of additives indicated in Fig. 1. The GlcA (gluconolactone), however, was added on Day 11 postinoculation. Means \pm SE $(n=3)$

growth are shown in Table 1. GlcA concentrations (repeated in 2 separate determinations) in the axenic cultures remained essentially unchanged.

When an experiment almost identical to that illustrated in Fig. 1 (except that the GlcA was added $11 \mathrm{~d}$ post inoculation) was run with non-axenic cultures of the same strain of Pseudo-nitzschia multiseries, some of the results were quite different (Fig. 2). The growth was robust, stable and proportionately responsive to the effect of doubled silicate; the GlcA had no apparent effect on cell production or appearance of individual diatom cells. The major differences occurred in the rates and amounts of DA produced. As expected, significant DA production was not apparent until after the stationary growth phase had been reached. The maximal production of DA recorded on the 27 th day of growth (much greater than produced 
in the axenic culture) actually occurred at the lower or standard level of silicate $(0.1 \mathrm{mM})$ where the cell growth was considerably less than that at $0.2 \mathrm{mM}$ silicate. Moreover DA concentration on the 27 th day in $0.1 \mathrm{mM}$ silicate cultures containing $0.25 \mathrm{mM}$ GlcA was $40 \%$ less than that in matching GlcA-free culture. However, addition of the same concentration of GlcA to cultures containing $0.2 \mathrm{mM}$ silicate had no effect. Comparisons of DA values (Fig. 2) on Day 27 using a paired $t$-test (Sokal \& Rohlf 1995) showed the concentrations for the two $0.1 \mathrm{mM}$ silicate growth curves were significantly different from one another and from concentrations for the $0.2 \mathrm{mM}$ silicate growth curves $(p<0.05)$. Trials with GlcA additions to non-axenic cultures during their logarithmic phase of growth led directly to the following experiment and the decision to increase the GlcA concentration to $0.5 \mathrm{mM}$.

My aim was to present the additives to cultures at the beginning of the stationary phase or when slowed cell division would be expected to occur (judging by previous trials with $0.1 \mathrm{mM}$ and $0.2 \mathrm{mM}$ silicate concentration diatom media). The impacts of the additives and their fates were then examined in more detail over a shorter time period (about $48 \mathrm{~h}$ ) than previously . The additives were presented to Pseudo-nitzschia multi- series cultures growing in 0.1 or $0.2 \mathrm{mM}$ silicate concentration culture medium (otherwise standard diatom medium) on Day 22 day post-inoculation. On that day, 3 culture flasks were left untreated and the remaining flasks in groups of 3 were supplemented to concentrations of $0.5 \mathrm{mM}$ GlcA, $5 \mathrm{mM}$ glucose or a combination of both (Fig. 3). DA concentrations measured in samples drawn at $0,2,4,18$ and $49 \mathrm{~h}$ following the additions on Day 22 are presented in Fig. 3B,C. The amounts of GlcA or glucose remaining in the cultures after $49 \mathrm{~h}$ incubation are given in Table 2 .

Significantly increased amounts of DA were apparent after $18 \mathrm{~h}$ in those cultures to which no additions had been made, and amounts were proportional to the numbers of cells produced (Fig. 3). Cell production in $0.2 \mathrm{mM}$ silicate medium was approximately double that in the $0.1 \mathrm{mM}$ silicate medium, as were the DA levels $49 \mathrm{~h}$ post addition.

Between 18 and $49 \mathrm{~h}$ post addition, the additives had markedly negative influences on DA concentrations. The addition of GlcA alone strongly retarded DA production at both silicate levels. Glucose alone brought about a reduction of DA from those levels present at zero time, while the combination of GlcA with glucose resulted in complete elimination of DA already present
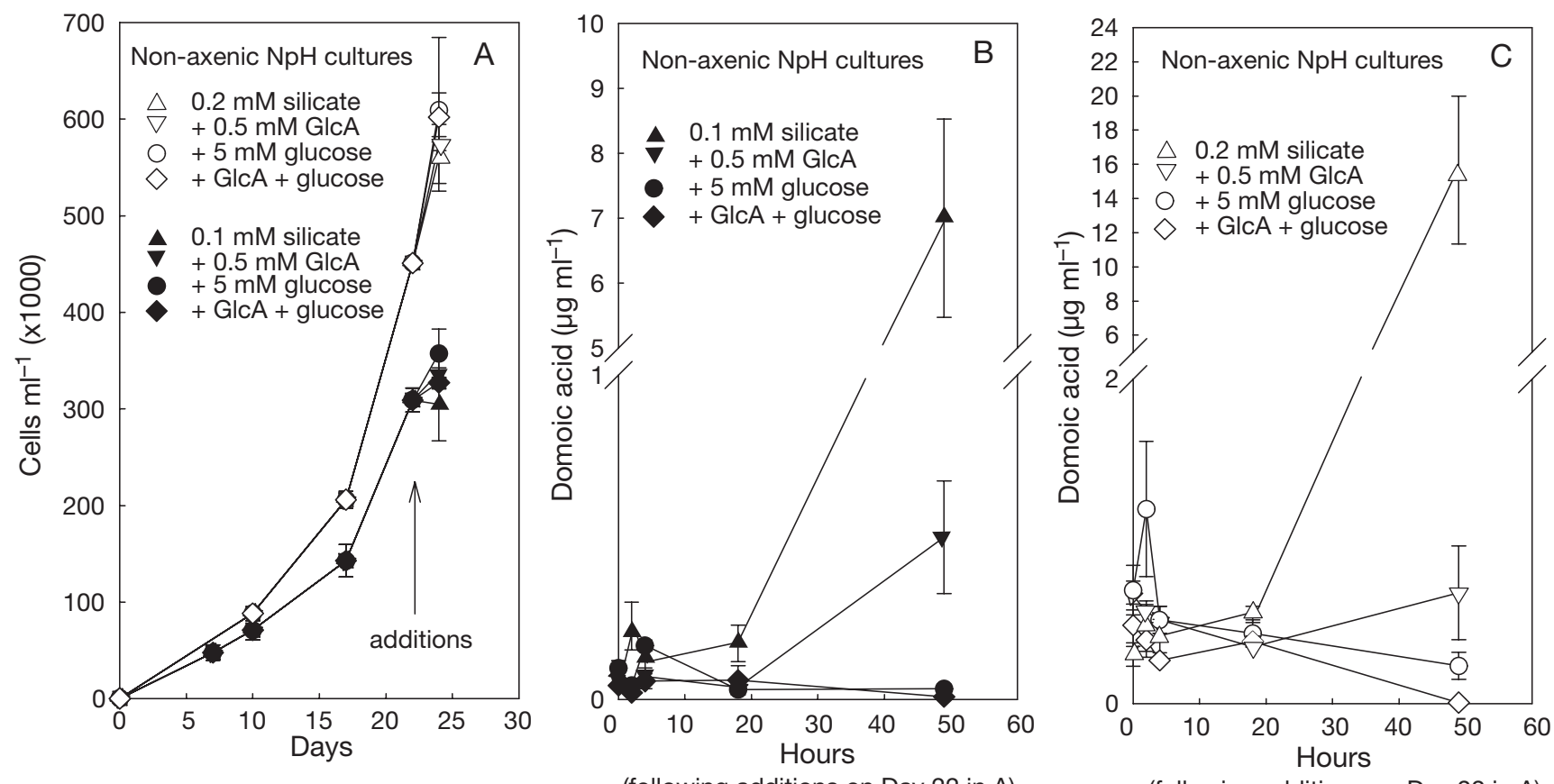

(following additions on Day 22 in A)

(following additions on Day 22 in A)

Fig. 3. Pseudo-nitzschia multiseries. (A) Growth of non-axenic cultures (strain $\mathrm{NpH}$ ) at $20^{\circ} \mathrm{C}$ in single and double silicate concentration media for $22 \mathrm{~d}$, at which time additives (GlcA [gluconolactone], glucose) singly and in combination were introduced to both sets of cultures and their influence followed over the ensuing $49 \mathrm{~h}$. (B) Effect on DA (domoic acid) production of the single additions or combinations of GlcA and glucose with the standard diatom medium ( $0.1 \mathrm{mM}$ silicate) in the $49 \mathrm{~h}$ period following the additions made on Day 22 (Fig. 3A). (C) Effect on DA production of the same additives at the same concentrations added to the standard diatom medium containing double the concentration of silicate $(0.2 \mathrm{mM})$ in the $49 \mathrm{~h}$ period following the addition on Day 22 (Fig. 3A). Means \pm SE $(n=3)$ 
Table 2. Pseudo-nitzschia multiseries concentrations $\left(\mu \mathrm{g} \mathrm{m}^{-1} \pm \mathrm{SE}, \mathrm{n}=3\right.$ ) of supplements added to 0.1 and $0.2 \mathrm{mM}$ silicate cultures on Day 22 of incubation (Initial) and after $49 \mathrm{~h}$ (Final). See Fig. 3. GlcA was prepared as $0.5 \mathrm{mM}$ solution, but as enzymatic determinations gave a higher value, these were used throughout as the base for comparison. GlcA = gluconolactone/gluconic acid $;$ Gluc $=$ glucose

\begin{tabular}{|lcccc|}
\hline \multirow{2}{*}{ Additives to: } & \multicolumn{4}{c}{ Concentrations } \\
\cline { 2 - 5 } & $\begin{array}{c}\text { Initial } \\
\text { GlcA }\end{array}$ & $\begin{array}{c}\text { Final } \\
\text { GlcA }\end{array}$ & $\begin{array}{c}\text { Initial } \\
\text { Gluc }\end{array}$ & $\begin{array}{c}\text { Final } \\
\text { Gluc }\end{array}$ \\
\hline $\mathbf{0 . 1} \mathbf{~ m M}$ silicate cultures & & & \\
a) GlcA & $116 \pm 2$ & $106 \pm 4.9$ & & \\
$\begin{array}{l}\text { b) Gluc } \\
\text { c) GlcA } \\
\quad+\text { Gluc }\end{array}$ & $116 \pm 2$ & $109 \pm 5.2$ & 900 & $480 \pm 68.2$ \\
$\begin{array}{l}\mathbf{0 . 2} \mathbf{~ m M} \text { silicate cultures } \\
\text { a) GlcA } \\
\text { b) Gluc }\end{array}$ & $116 \pm 2$ & $113.7 \pm 3.2$ & 900 & $645 \pm 62.4$ \\
$\begin{array}{l}\text { c) GlcA } \\
+ \text { Gluc }\end{array}$ & $116 \pm 2$ & $111.7 \pm 4.2$ & 900 & $718.7 \pm 68.2$ \\
& & & 900 & $534.7 \pm 65.8$ \\
\hline
\end{tabular}

at the zero hour addition mark. GlcA concentration remained essentially unchanged over the $49 \mathrm{~h}$ examination period; depending on the particular culture, between one third and one half the glucose added disappeared (Table 2).

To determine whether the reduction and elimination of these DA concentrations was a result of (1) absorption and utilization of the DA by the diatom or (2) elimination of the DA by bacteria associated with the diatom, the following examinations were carried out. An axenic diatom culture in 4 flasks each charged with $30 \mathrm{ml}$ of standard diatom medium at a concentration of $0.2 \mathrm{mM}$ silicate was grown for $20 \mathrm{~d}$. Near the begin-

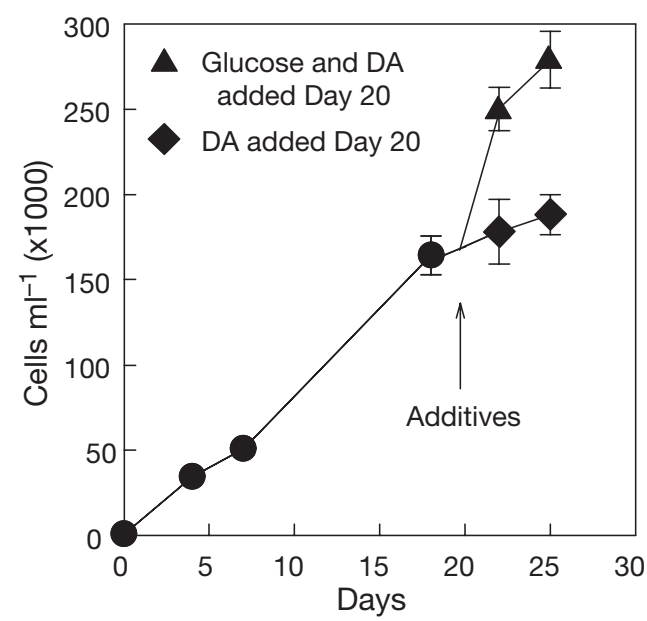

Fig. 4. Pseudo-nitzschia multiseries. Growth of axenic cultures in standard diatom medium containing $0.2 \mathrm{mM}$ silicate with addition on Day 20 of DA $\left(5 \mu \mathrm{g} \mathrm{ml}^{-1}\right)$ or DA plus glucose (5 $\mu \mathrm{g} \mathrm{ml}^{-1}$ and $5 \mathrm{mM}$, respectively) (see also Table 3). Means $\pm \operatorname{SE}(n=2)$ ning of the stationary growth phase (i.e. on Day 20), 2 of the flasks were exposed to DA $\left(5 \mu \mathrm{g} \mathrm{ml}^{-1}\right)$ plus glucose $(5 \mathrm{mM})$ and 2 flasks to DA alone (5 $\left.\mu \mathrm{g} \mathrm{ml}^{-1}\right)$ (Fig. 4). The addition of glucose restored Pseudo-nitzschia multiseries to a logarithmic growth phase resulting in a $50 \%$ greater cell production than in those cultures supplied with DA alone. The amount of glucose remaining at the end of the $5 \mathrm{~d}$ exposure was $605 \pm \mathrm{SE}=1 \mu \mathrm{g} \mathrm{ml}^{-1}$ (n = 3), approximately a one third utilization. The amounts of DA added were not changed significantly at any point in the $5 \mathrm{~d}$ exposure in either of the 2 sets of cultures (Table 3).

To test the possibility of DA elimination by bacteria associated with the diatom, the mixture of bacteria separated from the diatom by filtration was inoculated into yeast extract broth medium (MacLeod 1968) with DA (12.5 $\mu \mathrm{g} \mathrm{ml} \mathrm{m}^{-1}$ ) and without DA, glucose (5 mM), gluconic acid/gluconolactone $(0.5 \mathrm{mM})$ or various combinations of these. In all instances, bacteria grew over the $6 \mathrm{~d}$ incubation period (Fig. 5). In contrast to axenic Pseudo-nitzschia multiseries cultures (Table 3), the bacterial mixture separated from the non-axenic diatom culture reduced the DA concentrations by 46 to $72 \%$, depending upon the co-additives (Table 4).

The growth levels and DA production of one of the Pseudo-nitzschia multiseries cultures transferred frequently over a period of approximately $10 \mathrm{yr}$ were markedly reduced (Fig. 6). Its growth was enhanced significantly by increasing the silicate levels in the medium, and DA levels also increased in relation to the increased number of cells. While concentrations of DA in the cells were very low to non-existent, peak levels in the culture filtrate, although low, were significant and generally related to the diatom's growth until Day 16 of incubation. By then the DA produced had virtually disappeared from the culture.

Table 3. Pseudo-nitzschia multiseries DA (domoic acid) residues $\left(\mu \mathrm{g} \mathrm{ml} \mathrm{m}^{-1} \pm \mathrm{SE}, \mathrm{n}=2\right.$ ) remaining in axenic cultures after 5 d incubation (see Fig. 4). There were no significant differences between initial and final DA concentrations in either trial (0 h vs. 5 d; paired $t$-tests [Sokal \& Rohlf 1995] p < 0.05)

\begin{tabular}{|lcc|}
\hline \multirow{2}{*}{ Duration of exposure } & \multicolumn{2}{c|}{$\begin{array}{c}\text { Additives } \\
\text { DA + glucose }\end{array}$} \\
\hline $0 \mathrm{~h}$ & $5.04 \pm 0.16$ & $4.82 \pm 0.10$ \\
$24 \mathrm{~h}$ & $4.76 \pm 0.00$ & $4.86 \pm 0.18$ \\
$48 \mathrm{~h}$ & $4.68 \pm 0.04$ & $4.66 \pm 0.06$ \\
$70 \mathrm{~h}$ & $4.82 \pm 0.26$ & $4.58 \pm 0.14$ \\
$5 \mathrm{~d}$ & $4.40 \pm 0.08$ & $4.58 \pm 0.38$ \\
\hline
\end{tabular}




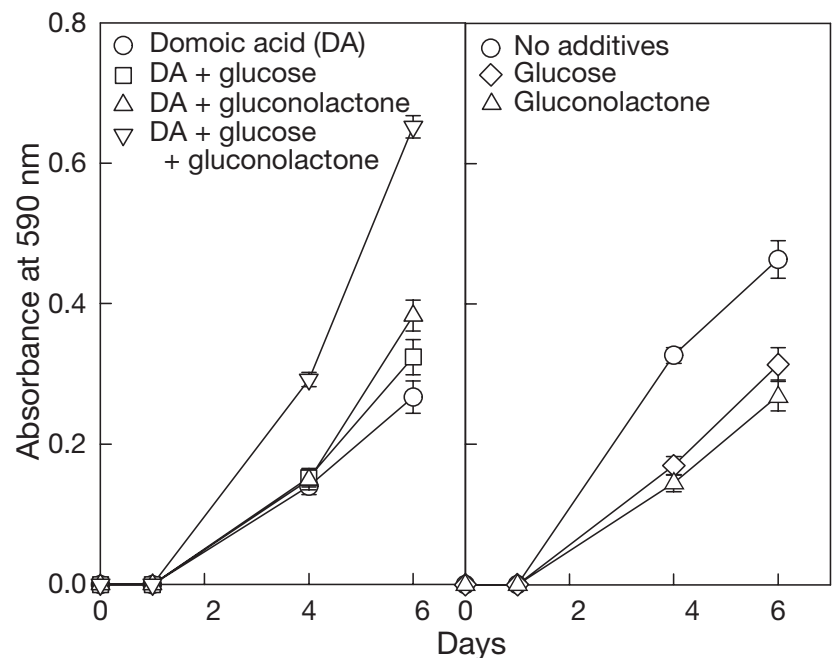

Fig. 5. Growth curves at $20^{\circ} \mathrm{C}$ of bacterial mixtures from cultures of Pseudo-nitzschia multiseries (strain $\mathrm{NpH}$ ) in yeast extract broth medium (MacLeod 1968) supplemented as indicated. Initial concentrations of DA (domoic acid), glucose and gluconic acid/gluconolactone were $12.5 \mu \mathrm{g} \mathrm{ml}^{-1}, 5.0 \mathrm{mM}$ and $0.5 \mathrm{mM}$, respectively. In mixtures of supplements (DA + glucose, DA + gluconic acid/gluconolactone, DA + glucose + gluconic acid/gluconolactone), these concentrations were maintained. Means $\pm \mathrm{SE}(\mathrm{n}=4)$

Thus, although the DA outputs had declined greatly compared to the culture's capacity earlier in its history, they were still appreciable. If however, the measurements had been made only at the end of the incubation period or on a culture grown with the lowest level of silicate when the small, but measurable amount of DA produced had been eliminated, the diatom would have been considered a non-producer.

In the culture grown with the highest levels of silicate $(0.4 \mathrm{mM})$ (Fig. 6), the cells in the stationary

Table 4. Bacterial utilization of domoic acid (DA, $\mu \mathrm{g} \mathrm{m}{ }^{-1}$ ) at $20^{\circ} \mathrm{C}_{i}$ initial concentration for all culture additives was $12.5 \mu \mathrm{g}$ DA $\mathrm{ml}^{-1}$. Confidence intervals (CI) calculated for the final concentrations indicate significant declines in domoic acid following the $6 \mathrm{~d}$ incubation ( $\mathrm{p}<0.05, \mathrm{n}=4$ ). Bacteria isolated from non-axenic cultures of Pseudo-nitzschia multiseries

\begin{tabular}{|lcc|}
\hline Culture additive & DA final conc. & CI \\
\hline 1) DA & 3.50 & $1.43-5.57$ \\
2) DA + glucose (5 mM) & 4.75 & $3.95-5.55$ \\
3) DA + gluconic acid/ & & \\
$\quad$ gluconolactone $(0.5 \mathrm{mM})$ & 6.75 & $5.95-7.55$ \\
4) DA + glucose $(5 \mathrm{mM})$ & 5.88 & $4.00-7.98$ \\
$\quad$ + gluconic acid/ & & \\
$\quad$ gluconolactone $(0.5 \mathrm{mM})$ & & \\
\hline
\end{tabular}

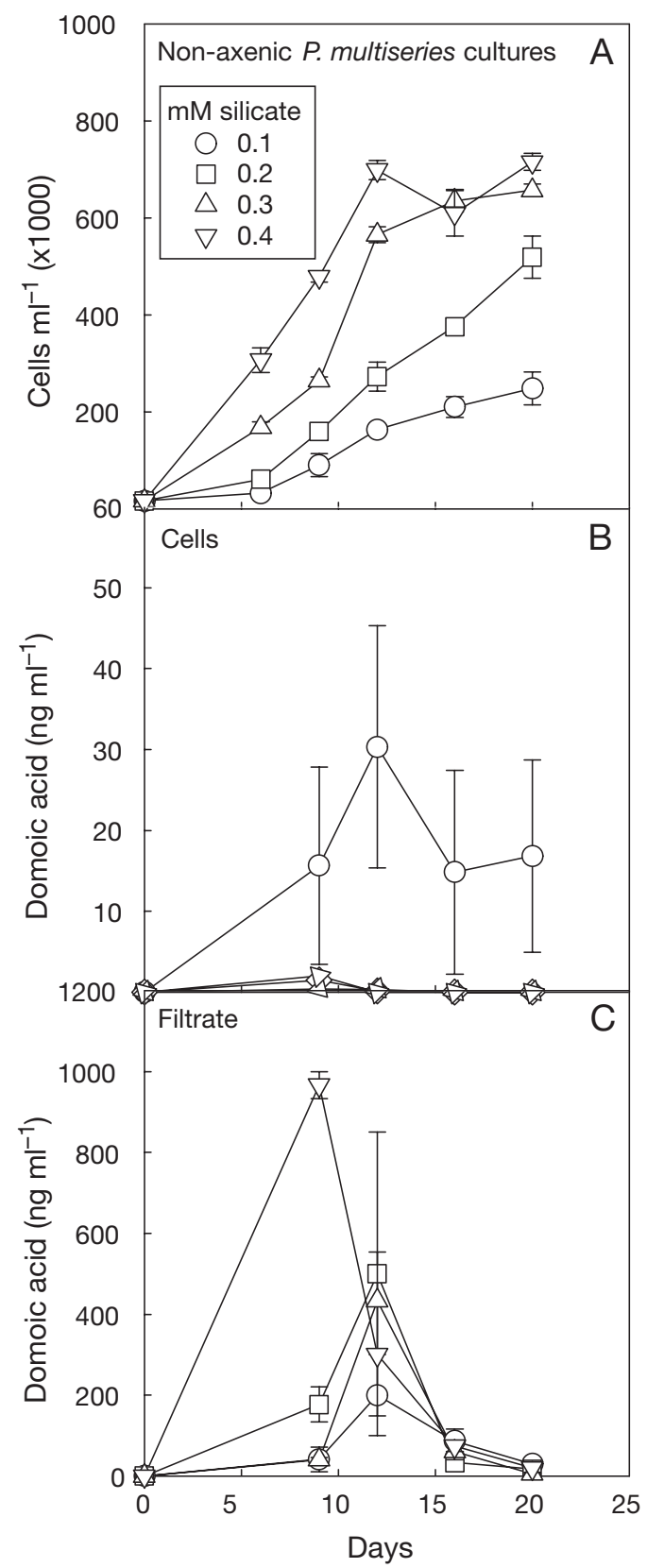

Fig. 6. Pseudo-nitzschia multiseries. (A) Growth curves and $(\mathrm{B}, \mathrm{C}) \mathrm{DA}$ (domoic acid) production at $20^{\circ} \mathrm{C}$ of an aging nonaxenic culture. Medium supplemented with silicate as indicated. (B) DA concentrations within diatom cells; (C) DA concentrations in cell-free filtrates prepared from whole cultures. Means $\pm \mathrm{SE}(\mathrm{n}=3)$

phase were distorted and incomplete, conforming to protoplast formation as described by Lewin (1962) and von Stosch (1942). As reported by von Stosch (1942), when the medium was supplemented with manganese $\left(133 \mathrm{\mu g} \mathrm{l}^{-1}\right)$ this deficiency was overcome and the frustule formation proceeded normally. 


\section{DISCUSSION}

Studies by earlier workers such as Jørgensen (1952) and Lewin $(1955,1957)$ showed that in media composed of sea water supplemented with $\mathrm{N}, \mathrm{P}$, trace metals and vitamins, silicon supply was deficient and diatom growth was directly, immediately and proportionately increased by raising the silicon concentrations. This proved to be true with the medium used in these studies; growth of both axenic and non-axenic Pseudo-nitzschia multiseries cultures responded directly and proportionately to a doubling of the silicate concentrations although the non-axenic culture was, by far, the more robust and stable.

Again, as shown by Osada \& Stewart (1997), GlcA added to the axenic cultures, although not affecting growth, increased the amount of DA present. In this case (Fig. 1) doubling the silicate alone matched the influence of GlcA alone; when the presence of the GlcA was coupled with increased silicate, however, there was a tripling of the DA concentration. Under the circumstances prevailing here, i.e. where substantial quantities of the sequestering agent gluconic acid/ gluconolactone were present after growth had peaked, the resulting enhanced accumulation of DA would appear to be consistent with the earlier hypothesis (Osada \& Stewart 1997) that DA may act on behalf of Pseudo-nitzschia multiseries as a chemical scavenger.

Although the presence of GlcA in the non-axenic cultures did not appear to affect its growth (Fig. 2), its effect on the production of DA seemed to be the reverse of that observed in the axenic cultures. Somewhat less DA was produced in its presence rather than more. An explanation for this is not readily available and must await further investigation; presumably the effect arises from the interaction of GlcA with certain of the bacteria present.

When these aspects were examined in detail over a much more restricted time period (Fig. 3) it was apparent that, in fact, increases in silicate concentrations resulted in enhanced DA accumulations directly related to increases in diatom cell production. In marked contrast to results with axenic cultures, where GlcA stimulated DA production, the GlcA introduced alone to non-axenic cultures appeared to have retarded DA production in the period between the 18th and 49th hours post-addition time. Glucose added alone resulted in a subsequent significant reduction in DA present at the time the additions were made, but when coupled with GlcA, there was complete disappearance of DA formed at and subsequent to the introduction of the additives. The speed with which the various major changes in DA concentrations occurred, both positive and negative was impressive. These results immediately raised questions as to the reasons for DA disappearance. Previously Stewart et al. (1998) showed bacteria isolated from association with Pseudo-nitzschia multiseries had the capacity to grow at the expense of DA. As bacteria mutate rapidly and constantly, the resulting populations that already have this basic capacity would be expected to become ever more capable of successfully exploiting products found in their particular niche. Long-term culture of P. multiseries provides just such a niche for enhancement of bacteria initially endowed with the capability of utilizing DA.

Exposure of axenic Pseudo-nitzschia multiseries to DA, either alone or with added glucose over a $5 \mathrm{~d}$ period did not result in any significant changes in the concentrations of the added DA (Table 3). The added glucose, however, did stimulate the culture's growth, restoring it to the logarithmic phase, demonstrating that the diatom could use the glucose directly as an energy source to overcome impediments to growth. In contrast, when bacteria previously associated with $P$. multiseries were grown in the basal medium of MacLeod (1968) to which $12.5 \mu \mathrm{g} \mathrm{ml}^{-1} \mathrm{DA}$ was added, they grew readily utilizing substantial amounts of DA (Table 4).

These results, taken together with those of Subba Rao et al. (1990), Douglas \& Bates (1992), Bates et al. (1995), Osada \& Stewart (1997), Stewart et al. (1997) and Hagström et al. (2007), suggest a dynamic and competitive set of interactions influenced especially by the confining and artificial constraints imposed by batch culture conditions, operating as follows. DA is produced not at all or only in very small quantities through the diatom's logarithmic growth phase. As its growth slows upon entering the stationary phase through outgrowing one or another nutrient, it experiences nutrient stress and DA production begins or is greatly enhanced. In axenic culture, its production is also stimulated by specific bacteria acting in concert with nutrient stress (Douglas \& Bates 1992, Bates et al. 1995). At this point, with production of DA in appreciable quantities, the bacteria associated with the diatom and capable of utilizing moderate concentrations of DA would be enhanced and begin using the DA released to the medium. Thus the amount of DA measured in the culture medium at any one time would be a balance between the diatom's DA production rate enhanced by bacterial stimulation and bacterial consumption of DA. If, however, the nutrient stresses are relieved by the addition of nutrients, e.g. glucose as in this study, or by proline or glutamic acid in axenic cultures (Osada \& Stewart 1997), the production of DA ceases or slows. Following the cessation of its production, DA-utilizing bacteria in non-axenic cultures would eliminate amounts already produced. A continuing apparent increase of DA in a non-axenic culture medium indicates vigorous production by the diatom 
exceeding the amount used by the bacteria. By contrast, in an aging culture in which the specific bacteria responsible for stimulating DA production have declined or disappeared (Douglas \& Bates 1992, Bates et al. 1995), a lessened DA production occurs coupled with a continued or increased rate of bacterial utilization leading to complete elimination similar to the results presented in Fig. 6. It is also logical to suggest that the bacteria isolated earlier from mussels and soft shell clams and capable of growing at the expense of DA (Stewart et al. 1998) might in fact have been bacteria originally associated with Pseudo-nitzschia multiseries and thus consumed by the bivalves.

This suggested explanation for the disappearance of the DA is also consistent with reports (Bates 1998) that as Pseudo-nitzschia multiseries cultures age, they gradually lose the ability to produce DA. Such an explanation raises a number of questions including the merits of the common practice of rating $P$. multiseries DA production by the number of picograms of toxin produced per cell. The number of cells can alter dramatically and suddenly. Much of the DA is released by the diatom to the aquatic medium, especially in the late logarithmic and stationary phases of growth, where it could become generally available to bacterial attack. Rating the production only or mainly by the picograms per diatom cell apparent at the time of measurement would be misleading as it implies that the number of diatom cells is the sole determinant of DA concentrations in the cultures.

Thus the production of DA is complex involving the diatom, nutrient stress and at least 2 quite different bacterial influences, one stimulatory and the other degradative. The information currently available suggests that a more detailed investigation of the everchanging interactions of bacteria associated with the diatom is essential to fully understand the dynamics of DA production.

Acknowledgements. I thank P. Kepkay and V. Zitko for their constructive criticism of a draft of the manuscript, C. Murphy and G. Burns for the HPLC DA determinations and S. Smith for statistical advice and assistance.

\section{LITERATURE CITED}

Bates SS (1998) Ecophysiology and metabolism of ASP toxin production. In: Anderson DM, Cembella AD, Hallegraeff GM (eds) Physiological ecology of harmful algal blooms. Springer, Berlin, p 405-426

Bates SS (2000) Domoic-acid-producing diatoms: another genus added! J Phycol 36:978-983

Bates SS, Bird CJ, de Freitas ASW, Foxall R and others (1989) Pennate diatom Nitzschia pungens as the primary source of domoic acid, a toxin in shellfish from eastern Prince Edward Island, Canada. Can J Fish Aquat Sci 46: $1203-1215$
Bates SS, de Freitas ASW, Milley JE, Pocklington R, Quilliam MA, Smith JC, Worms J (1991) Controls on domoic acid production by the diatom Nitzschia pungens f. multiseries in culture: nutrients and irradiance. Can J Fish Aquat Sci 48:1136-1144

Bates SS, Worms J, Smith JC (1993) Effects of ammonium and nitrate on growth and domoic acid production by Nitzschia pungens in batch culture. Can J Fish Aquat Sci 50:1248-1254

Bates SS, Douglas DJ, Doucette GJ, Leger C (1995) Enhancement of domoic acid production by reintroducing bacteria to axenic cultures of the diatom Pseudo-nitzschia multiseries. Nat Toxins 3:428-435

Bird CJ, Boyd RK, Brewer D, Craft CA and others (1988) Identification of domoic acid as the toxin agent responsible for the PEI contaminated mussel incident: a summary of work conducted at the Atlantic Research Laboratory of the National Research Council, Halifax, between 13 December, 1987 and 11 January, 1988. In: Atlantic Research Laboratory Technical Report No. 56 (NRCC-29083). National Research Council Canada, Halifax

Douglas DJ, Bates SS (1992) Production of domoic acid, a neurotoxic amino acid, by an axenic culture of the marine diatom Nitzschia pungens f. multiseries Hasle. Can J Fish Aquat Sci 49:85-90

Gilgan MW, Burns BG, Landry GJ (1990) Distribution and magnitude of domoic acid contamination of shellfish in Atlantic Canada during 1988. In: Granéli E, Sundström B, Edler L, Anderson DM (eds) Toxic marine phytoplankton. Elsevier, New York, p 469-474

Hagström JA, Granéli E, Maneiro I, Barreiro A, Petermann A, Svensen C (2007) Release and degradation of amnesic shellfish poison from decaying Pseudo-nitzschia multiseries in presence of bacteria and organic matter. Harmful Algae 6:175-188

Harrison PJ, Waters RE, Taylor FJR (1980) A broad spectrum artificial seawater medium for coastal and ocean phytoplankton. J Phycol 16:28-35

Hasle GR (1995) Pseudo-nitzschia pungens and P. multiseries (Bacillariophyceae): nomenclatural history, morphology, and distribution. J Phycol 31:428-435

Jørgensen EG (1952) Effects of different silicon concentrations on the growth of diatoms. Physiol Plant 5:161-170

Kaczmarska I, Ehrman JM, Bates SS, Green DH, Léger C, Harris J (2005) Diversity and distribution of epibiotic bacteria on Pseudo-nitzschia multiseries (Bacillariophyceae) in culture, and comparison with those on diatoms in native seawater. Harmful Algae 4:725-741

Kotaki Y, Koike K, Yoshida M, Thuoc CV and others (2000) Domoic acid production in Nitzschia sp. (Bacillariophyceae) isolated from a shrimp-culture pond in Do Son, Vietnam. J Phycol 36:1057-1060

Lewin JC (1955) Silicon metabolism in diatoms: II. Sources of silicon for growth of Navicula pelliculosa. Plant Physiol 30:129-134

Lewin JC (1957) Silicon metabolism in diatoms: IV. Growth and frustule formation in Navicula pelliculosa. Can J Microbiol 3:427-433

Lewin JC (1962) Silification. In: Lewin RA (ed) Physiology and biochemistry of algae. Academic Press, New York, p 445-465

Lundholm N, Moestrup Ø (2000) Morphology of the marine diatom Nitzschia navis-varingica, sp. nov. (Bacillariophyceae), another producer of the neurotoxin domoic acid. J Phycol 36:1162-1174

MacLeod RA (1968) On the role of inorganic ions in the physiology of marine bacteria. Adv Microbiol Sea 1:95-126 
McLachlan DG, Lawrence AH, Elias L (1993) Rapid IMS analysis for the shellfish biotoxin, domoic acid. Abstract. 39th Canadian Spectroscopy Conference.

Mos L (2001) Domoic acid: a fascinating marine toxin. Environ Toxicol Pharmacol 9:79-85

> Osada M, Stewart JE (1997) Gluconic acid/gluconolactone: physiological influences on domoic acid production by bacteria associated with Pseudo-nitzschia multiseries. Aquat Microb Ecol 12:203-209

Osada M, Marks LJ, Stewart JE (1995) Determination of domoic acid by two different versions of a competitive enzyme-linked immunosorbent assay (ELISA). Bull Environ Contam Toxicol 54:797-804

Pan Y, Subba Rao DV, Mann KH, Brown RG, Pocklington R (1996a) Effects of silicate limitation on production of domoic acid, a neurotoxin, by the diatom Pseudo-nitzschia multiseries. I. Batch culture studies. Mar Ecol Prog Ser 131:225-233

Pan Y, Subba Rao DV, Mann KH, Li WKW, Harrison WG (1996b) Effects of silicate limitation on production of domoic acid, a neurotoxin, by the diatom Pseudo-nitzschia multiseries. II. Continuous culture studies. Mar Ecol Prog Ser 131:235-243

Pan Y, Subba Rao DV, Mann KH (1996c) Changes in domoic acid production and cellular chemical composition of the toxigenic diatom Pseudo-nitzschia multiseries under phosphate limitation. J Phycol 32:371-381

Perl TM, Bedard L, Kosatsky T, Hockin JC, Todd ECD, McNutt LA, Remis RS (1990) An outbreak of toxic encephalopathy caused by eating mussels contaminated with domoic acid. N Engl J Med 322:1775-1780

Quilliam MA, Sim PG, McCulloch AW, McInnes AG (1989) High performance liquid chromatography of domoic acid, a marine neurotoxin, with application to shellfish and plankton. Int J Environ Anal Chem 36:139-154

Rhodes L, Scholin C, Garthwaite I (1998) Pseudo-nitzschia in New Zealand and the role of DNA probes and immunoassays in refining marine biotoxin monitoring programmes. Nat Toxins 6:105-111

Shimizu Y, Gupta S, Masuda K, Maranda L, Walker CK, Wang R (1989) Dinoflagellate and other microalgal toxins: chemistry and biochemistry. Pure Appl Chem 61:513-516

Sokal RR, Rohlf FJ (1995) Biometry: the principles and

Editorial responsibility: Hugh MacIntyre,

Dauphin Island, Alabama, USA practice of statistics in biological research, 3rd edn. WH Freeman, New York

Stewart JE, Marks LJ, Woods CR, Risser SM, Gray S (1997) Symbiotic relations between bacteria and the domoic acid producing diatom, Pseudo-nitzschia multiseries and the capacity of these bacteria for gluconic acid/gluconolactone formation. Aquat Microb Ecol 12:211-221

Stewart JE, Marks LJ, Gilgan MW, Pfeiffer E, Zwicker BM (1998) Microbial utilization of the neurotoxin domoic acid: blue mussels (Mytilus edulis) and soft shell clams (Mya arenaria) as sources of the microorganisms. Can J Microbiol 44:456-464

Subba Rao DV, Quilliam MA, Pocklington R (1988) Domoic acid - a neurotoxic amino acid produced by the marine diatom Nitzschia pungens in culture. Can J Fish Aquat Sci 45:2076-2079

Subba Rao DV, de Freitas ASW, Quilliam MA, Pocklington R, Bates SS (1990) Rates of production of domoic acid, a neurotoxic amino acid in the pennate marine diatom Nitzschia pungens. In: Granéli E, Sundström B, Edler L, Anderson DM (eds) Toxic marine phytoplankton. Elsevier, New York, p 413-417

Subba Rao DV, Pan Y, Mukhida K (1998) Production of domoic acid by Pseudo-nitzschia multiseries Hasle, affected by lithium. PSZN I: Mar Ecol 19:31-36

Todd ECD (1990) Amnesic shellfish poisoning-a new seafood toxin syndrome. In: Granéli E, Sundström B, Elder L, Anderson DM (eds) Toxic marine phytoplankton. Elsevier, New York, p 504-508

Todd ECD (1993) Domoic acid and amnesic shellfish poisoning - a review. J Food Prot 56:69-83

Villac MC, Roelke DL, Villareal TA, Fryxell GA (1993) Comparison of two domoic acid-producing diatoms: a review. In: van Dam H (ed) Twelfth International Diatom Symposium. Hydrobiologia 269/270:213-224

von Stosch HA (1942) Form und Formwechsel der Diatomee Achnanthes longipes in Abhängigkeit von der Ernährung. Mit besonderer Berücksichtigung der Spurenstoffe. Ber Deut Botan Ges 60:2-16

Wright JLC, Boyd RK, de Freitas ASW, Falk M and others (1989) Identification of domoic acid, a neuroexcitatory amino acid, in toxic mussels from eastern Prince Edward Island. Can J Chem 67:481-490

Submitted: June 5, 2007; Accepted: October 5, 2007 Proofs received from author(s): December 18, 2007 